\title{
Colonial Normativity? Corruption in the Dutch-Indonesian Relationship in the Nineteenth and Early Twentieth Centuries
}

Ronald Kroeze

\section{INTRODUCTION}

There are many historical accounts that, one way or the other, have linked Dutch colonial rule of Indonesia to corruption. Works of historians have pointed at how the existence of a variety of corrupt practices, from bribery and patronage to all kinds of "extractive institutions", undermined social and economic development. ${ }^{l}$ Others have paid attention to singular corruption scandals, ${ }^{2}$ or touched upon the theme of corruption in their analyses of ideological debates about decline and reform in the wake of the end of the Dutch United East India Company (Vereenigde Oostindische Compagnie/ VOC), and the emergence of the modern colonial state from around the year $1800 .^{3}$ In the decades around 1900,

R. Kroeze $(\bowtie)$

Vrije Universiteit Amsterdam, Amsterdam, The Netherlands e-mail: d.b.r.kroeze@vu.nl

(C) The Author(s) 2021

R. Kroeze et al. (eds.), Corruption, Empire and Colonialism in the Modern Era, Palgrave Studies in Comparative Global History, https://doi.org/10.1007/978-981-16-0255-9_7 
corruption was linked to the granting and use of concession rights by big companies active in the colony, ${ }^{4}$ as well as to how public morality was understood and maintained by the colonial police. ${ }^{5}$ Even the famous novel Max Havelaar (1860), an accusation against colonial abuses written by the former colonial administrator Eduard Douwes Dekkers, can be considered as a book mainly about corruption. ${ }^{6}$ One of the rare academic texts that has colonial corruption as its main theme was written by Willem Wertheim in 1961. Wertheim, a former colonial official and thereafter a professor of sociology and modern history of Southeast Asia, took Max Havelaar as a starting point for an article on corruption in colonial Indonesia; however, it is brief. ${ }^{7}$ Moreover, although he takes a critical stance and he acknowledges the involvement of Dutch officials and entrepreneurs in cases of corruption, he struggles with both the concept of corruption as well as "Weberian style bureaucratization", when he writes that the Dutch were hindered in their attempt to curb corruption and introduce modern government by "patrimonial" indigenous elites and local circumstances. He concludes that "as far as civil servants were incorruptible it was more because of sharp surveillance by European administrative institutions than that the Indonesian civil servants had embraced the new public ethics". ${ }^{8}$ The examples of corruption he offers are, however, interesting in their variety: from bribery to nepotism, and from misuse of power to forms of illicit influencing and lobbying. In short, we can conclude that despite several examples, the relationship between corruption, colonial exploitation and modern empire-building has not been systematically investigated, whereas the relevance of this topic has been acknowledged, also more recently. ${ }^{9}$ Although such a research project would require a systematic analysis of different case studies, international comparison and cooperation with historians from Indonesia, which is what we do in the project Colonial Normativity, ${ }^{10}$ this text is an attempt to locate the topic of colonial corruption within the history of Dutch-Indonesian relations during the nineteenth and early twentieth centuries, informed by historiographical trends and original research that was earlier executed.

The ambiguities surrounding the concept of corruption probably have contributed to the lack of research so far. At first sight, issues as diverse as bribery, tax farming, patronage, deviating sexual norms, the decadence of the colonial elite or the decay of an entire colonial system have been linked to corruption, both by contemporaries and historians. Moreover, what is immoral to one, is not necessarily to the other, as understandings of corruption depend on ideological, political and cultural positions 
that differ-also over time and place. Recent historical research, however, of which the contributors of this volume have contributed to, provides methods and insights on how to deal with these challenges.

First, researching corruption in different cultural and historical circumstances requires a contextual approach. Corruption can be understood as a deviation or putrefaction of something that was originally pure and good, and it has been defined as the misuse of public power and resources for private gain. However, the precise meaning of misuse, private gain and public power can only be understood when corruption is analysed in its specific social, legal and historical context. ${ }^{11}$ In more concrete terms, one could analyse publicly debated cases of misuse of public power or scandals, and be sensitive to what contemporaries considered to be corruption, as well as for what reasons. Moreover, the "politics of corruption" should not be forgotten. Throughout history, accusations of corruption were useful political weapons-as were campaigns against corruption in the name of just rule or good government; they might have intended reform and been supported by many, they often also strengthened the access to power and resources of some, while still undermining those of others. ${ }^{12}$

With regard to the colonial setting, there are more things to keep in mind. As Xavier Huetz de Lemps shows in his contribution about the Philippines, the colony is a place where very different groups-ordinary people, indigenous elites, intermediaries of different descent, Western colonisers-live and compete for power and resources. These different groups share, but also obey, different values and norms. This "plurality of norms" can lead to "competition of norms", 13 which can cause disputes about what is acceptable public and private behaviour that can turn into accusations of and debates about corruption, as historical research has shown. ${ }^{14}$ Furthermore, corruption in a colonial setting is not about the colony only, but takes place in an imperial context in which the metropole and colony influence each other. ${ }^{15}$ Like Mark Knights and Zak Leonard, Pol Dalmau and Tanja Bührer show in their respective contributions to this volume, political changes in the metropole can have a huge impact on what is considered corruption. And as Jonathan Saha argues, the relationship between administration and society in the colony and in the metropole influences understandings of colonial corruption.

In order to further develop this argument, I focus on the Netherlands-Indonesian case and start by explaining how the historiography on European corruption, including the idea of an emergence of a so-called "modern" understanding of corruption from around 1800, has inspired 
me to locate the topic of corruption in the history of colonial rule of Indonesia. After having introduced the topic of colonial corruption in relation with ideas of "progress" in the decades around 1800, I continue by discussing colonial corruption in the light of the history of the "Cultivation System" (1830s-1870s), the "Liberal period" and the "Ethical Policy" (officially launched in 1901) - the Dutch equivalent of the civilising mission. ${ }^{16}$ In the final sections of this chapter, I try to shed light on the persistence of corruption in the history of the Dutch-Indonesian relationship.

\section{Corruption AND Reform in Europe ANd the Colony: An EnTANgled History?}

Recent years saw a series of publications on the role of corruption in the process of European state formation since the late eighteenth century. ${ }^{17}$ From these studies, it can be distilled that corruption came in many forms, but also had recurrent features: in public debates corruption stood for the bad, immoral and rotten elements of politics and society. Additionally, corruption was often understood as the abuse of public power, trust or resources for private (or group) benefit. Nonetheless, as mentioned above, one should not forget that morality, abuse or the public-private divide were understood differently over time and place. Next, these studies have shown how denunciators accused others of corruption ${ }^{18}$ and that systematic anticorruption campaigns were useful weapons to undermine opponents and what they stood for. ${ }^{19}$

Although some debate remains about how sharp the break with the past was, historians have also pointed to the emergence of a new "modern" understanding of corruption in political discourse from around $1800 .^{20}$ From the perspective of corruption, the French Revolution, and its counterparts, could be understood as an attack on all kinds of practices (e.g. tax farming, gifts, patronage, elite privileges), as well as the system they were a part of-the Ancien Régime-which became synonymous with corruption. In contemporary analyses, the mixing up of private (personal, family and faction) and public (state, general, national or people's) interests was at the heart of what was wrong with the Ancien Régime. Reformers argued that corruption could only be rooted out with a radical change of regime, to be followed by a clear separation of the public and private. Corruption became predominantly defined as the misuse of public office for private gain (although broader and general 
understandings of corruption as a (bad) deviation of something that was pure and whole before, remained in place as well). In the Netherlands, the failed Dutch Patriotic reform of the 1780s, or the reformers that successfully overthrew the old Dutch Republic of the United Provinces (1588-1795)—the Dutch Ancien Régime—and established the Batavian Republic in 1795, did use the more modern understanding of corruption when they argued for a regime change based on a legal and constitutional separation between the public and private. Church and state were separated and specific anticorruption laws were established that prohibited public servants from merging their public duties and private interests, such as bans on tax farming, the sale of offices and accepting gifts. ${ }^{21}$

Around 1800, the situation in the metropole and the overseas possessions influenced each other (see also the chapters by Tanja Bührer and Anubha Anushree). ${ }^{22}$ In the Netherlands-Indonesian situation, reformers argued that the corruption and decline of the old Dutch Republic was entangled with the corruption and decline of the Dutch United East India Company, the VOC (Vereenigde Oostindische Compagnie; whose full name could also be read as Vergaan Onder Corruptie 23 _Perished Under Corruption). The VOC had the monopoly on trade with Asia, but after periods of economic expansion and success became less profitable and lost terrain to the British East India Company (EIC), as well as to local trading networks. VOC officials often acted as representative of the VOC, local administrator, judge in legal disputes and trader, alike. Trading on their own account and keeping a share of the profit was also common and acceptable until a certain level-the VOC even regarded it as a means to prevent (more) corruption. However, by the end of the eighteenth century, due to patronage as well as the increasing financial inability of the VOC to maintain all of its positions in Southeast Asia, VOC representatives on the ground obtained and took more room. ${ }^{24}$ This met with criticism for different reasons. First, while the position of the VOC as a whole kept deteriorating, certain VOC officials took good care of themselves. In other places, the situation for the trading and governing elites was still rather good, such as on the North-East coast of Java, where due to a switch to the production of cash crops for the world market, profits continued to be made. ${ }^{25}$ Additionally, critical voices were inspired by the ideology of Republicanism, which went through a period of revival and emphasised the importance of (serving) the public interest, as well as Enlightenment ideas about popular sovereignty and creating progress through rationality and freedom (including free trade). 
They blamed VOC representatives for neither acting with civic virtuewith respect for the moral health of the Dutch Republic and general well-being-nor running their trading posts rationally and efficiently in order to enhance progress in the common interest. State-supported trade monopolies, such as the VOC was, became a symbol of everything that was wrong about the old regime.

When Dutch revolutionaries with French support replaced the Dutch Republic with the Batavian Republic (1795-1806), the VOC was first nationalised (1795) and then terminated (1799). Although Indonesian possessions were placed under a state committee in the Netherlands, the first years after the fall of the Ancien Régime continued to provide much discretionary powers to men on the spot-including to indigenous elites and Chinese traders. ${ }^{26}$

In 1806, the Batavian Republic was transformed into the Kingdom of Holland, a vassal state of the French empire with Louis Napoleon as its king, a brother of Emperor Napoleon. Louis Napoleon appointed Herman Willem Daendels, who served as Governor General of the Dutch East Indies from 1807 until 1810. In 1811, the British invaded Java and installed Sir Thomas Stamford Raffles; in the years of Daendels and Raffles, a series of reforms in the name of "progress" were initiated. They aimed to strengthening state control and create more room for free entrepreneurship - aims both ungirded by eliminating practices that were by that time labelled as corruption. Daendels, for example, challenged the powers of the old elites (Oudgastenpartij) known for patronage and nepotism. He also built, with the help of numerous ill-treated serviced labourers, the Grote Postweg-a road that cut across Java to improve communication, centralisation and state control. Raffles, in his rhetorical distancing of British rule from VOC rule, aimed for progress through turning local aristocrats into salaried officials by taking their privileges, such as overcharging, percentages and gifts, as well as by promoting free entrepreneurship and free labour, which he hoped could be directly taxed and end existing tax collecting practices, such as a tax farming. ${ }^{27}$

Thus, around the year 1800, regimes had been changed-both in the metropole and colony-in the name of eliminating corruption. Throughout the nineteenth century, patronage, sale of offices, tax farming, elite privileges, gifts and other examples of the combining of public and private continued to be denounced as corruption and to inspire reform. According to Jens Ivo Engels, the nineteenth century saw the rise of the absolute non-toleration of these forms of corruption. ${ }^{28}$ 
This is, of course, neither to say that privilege, patronage or other examples of corruption disappeared in historical reality, nor did the debate end about how to define (violations of) the right public-private relationship. On the contrary: the nineteenth century saw the birth of modern ideologies and parties that held different views on what was moral and corrupt in the respective public and private spheres. Nonetheless, manyfor example Liberals-continued to look critically at the principle of blurring public and private. The Dutch Liberal Johan Thorbecke, the man behind the introduction of the Dutch reformed constitution of 1848 , diagnosed that the blending of public and private interests, offices and the system of privileges, founded in custom law, was the main problem of the Ancien Régime and the foremost reason for the French Revolution and its European counterparts. ${ }^{29}$ Liberals became known for idealising the "art of separation": state and economy; religion and politics; morality and law. ${ }^{30}$ Later on, radical ideologies such as Socialism were also obsessed with altering the public-private divide by just denying the existence of a distinctive public and private sphere as a means to reach into the mythical corruption-free modern era. ${ }^{31}$

Another characteristic was that, in the wake of Enlightenment ideas about linear progress, ${ }^{32}$ the modern interpretation of corruption had a historical dimension. As corruption was discussed as a problem of the Ancien Régime, it became understood as a problem of the past, as one can derive from the work and speeches of politicians, publicists and historians in the nineteenth century. In Britain, politicians tried to solve what they called the problem of "old corruption"-i.e. bribing voters, the "sale" of offices in the form of offering lucrative positions (with emoluments) and honours to political friends in return for their support-which, in fact, characterised British politics far into the nineteenth century and beyond. However, these elements continued to be understood as being remnants from the past. ${ }^{33}$ For the Dutch case, Mary Lindeman, has pointed to the great number of texts on the corruption of the Dutch Republic that date from the second half of the nineteenth century, and the first half of the twentieth century-several of them written by prominent Dutch historians such as Robert Fruin and Pieter Geyl. ${ }^{34}$ These historians emphasised the use of patronage and "oligarchical" power structures (an oligarchy is an aristocratic government that is corrupted according to Classical political philosophy), the sale of offices and the famous "contracts of correspondence" that were used to divide and secure offices among the most prominent families in the Republic. ${ }^{35}$ In the same tradition, the 
Liberal reform of 1848 was regarded a turning point, as historian Chris te Lintum-while referring to the work of Fruin-stated in his book A century of progress in 1913. According to Te Lintum, it was at this moment that politics came under public scrutiny, and because of that, all past corruption was eliminated. ${ }^{36}$

The understanding of corruption as a problem of past regimes in combination with the self-confidence of the Dutch that they had reached into the corruption-free modern era, in a context of increasing nationalism, also gave rise to the argument that corruption belonged to "a foreign country", to a historical, cultural and geographical "Other". ${ }^{37}$ As with debates about corruption around the year 1800, which portrayed the VOC and the old Dutch Republic as remnants from a corrupt past, in mid- and late-nineteenth-century newspapers and parliamentary debates, corruption was linked firstly to British elections ("old corruption") and French politics (the country of the Ancien Régime par excellence), and later to "Eastern" or "Oriental" regimes such as the Austrian, Russian or Ottoman empires. Throughout this era, Dutch colonial possessions were also repeatedly debated as the corrupt "Other". This took place in a broader context of extending colonial borders and emerging imperialist and orientalist views, ${ }^{38}$ as is discussed below.

\section{The Nineteenth-Century Cultivation System: Breeding Ground for Corruption}

After the defeat of Napoleon between 1814 and 1815, the British returned the Dutch East Indies to the Netherlands as part of the British supported vision of the Netherlands as a middle-size power that would include colonial possessions. ${ }^{39}$ The autocratic King Willem I was keen on creating a new empire, with Java being the most important site of his "imperial phantasies", 40 and wanted to ensure that the colony could finance itself. Willem I thus stuck to development through the means on which the colonial reforms of around 1800 were based, such as centralisation of administrative powers and bureaucratisation of governing elites. The prosecuting of officials for bureaucratic corruption, such as in the case of high Dutch officials who took bribes in return for granting indigenous aristocrats with public offices, is evidence that the reforms indeed caused things to change. However, when the High Court had to decide about their punishment, it had to rely on structures of the VOC era that were more flexible to these forms of corruption. ${ }^{41}$ 
The same kind of plurality or competition of norms existed in the domain of economic policy. At first, Willem I promoted free entrepreneurship and free labour, but when this did not pay off as was hoped for, and also in response to the money-consuming Java War (18251830), a war itself clearly linked to the period of revolutions of around $1800,{ }^{42}$ he appointed Johannes van den Bosch as governor general in 1830. ${ }^{43}$ Van den Bosch introduced the infamous Cultivation System that was based on the claim that all the land belonged to the Dutch state and a government-controlled economic policy of entrepreneurship that historians have characterised as a "quasi-mercantilist exploitation". The Cultivation System also showed similarity with the eighteenth-century economic exploitation of Java by the VOC, as it was founded on forced labour and the support of the indigenous elites. ${ }^{44}$ Plantations had to cultivate what the colonial government ordered such as sugar, coffee, tea or indigo. The Netherlands Trading Society (Nederlandse Handelmaatschappij/ NHM), founded in 1824, was given the trade monopoly and sold the crops on the world market. In return, the state and NHM would guarantee stable prices that were relatively high. Dutch plantation supervisors and entrepreneurs, as well as the Dutch state, earned huge profits (batig slot), the latter used to finance infrastructural projects in the Netherlands. ${ }^{45}$ The overall growth of the global trade was one reason for its success; that the Cultivation System was based on forced labour, even after the formal abolition of enslavement in the Dutch East Indies in $1860,{ }^{46}$ was another. ${ }^{47}$

The indigenous elites also played a role in maintaining the system. The Dutch had established a system of dual rule in which Dutch colonial administrators - (assistant) residenten - and the local aristocratsregenten-governed together, as the Dutch could not rule and judge without "the information, networks, and prestige of the Javanese elite officials (priyayi)". ${ }^{48}$ Indigenous regents, in return for their support, were given land and seigneurial rights: local peasants had to dedicate a considerable amount of their time to work on princely lands without being paid. A separation of powers, the norm in the motherland at least formally, was absent; practically as the Dutch administrators remained in the position of ultimate arbiter, ideally as the "Oriental" nature required firm control of power in one hand, so it was argued. ${ }^{49}$

There are examples similar to this one. Tax farming, abolished in the metropole since it was regarded as one of the most evident examples of Ancien Régime corruption, ${ }^{50}$ continued to exist in Indonesia 
throughout the nineteenth century. The colonial government granted both local heads as well as Chinese middlemen the right to collect taxes and keep a percentage as remuneration. On the ground, a great variety of collecting mechanisms existed together with a great deal of wheeling and dealing, both between taxpayers and tax collectors, as well as between the colonial administrators and the tax collectors, providing ample opportunities for tensions, arbitrariness and outright misuse. ${ }^{51}$ The pivotal role of the Chinese middlemen in fiscal and economic matters went back to the time of the VOC: they had developed sophisticated means to both successfully collect and lend money. By the end of the nineteenth century, their role gave rise to the framing of the Chinese middlemen as immoral moneygrubbers, also fed by Dutch accusations and unease about the deteriorating circumstances of Javanese peasants who carried the heaviest tax burden. ${ }^{2}$

The plurality of norms that existed in the Dutch empire during the era of the Cultivation System, and the accompanying immoralities, formed a fertile breeding ground for debates about corruption and reform already since 1848 and especially from the 1860s onwards, when Liberals began to dominate Dutch politics. Liberal reformists asked for more room for private entrepreneurship as the state controlled the business sector too much and the colonial administration granted plantations to "friends", linking the Cultivation System to economic inefficiency as well as patronage and nepotism. Secondly, moral concerns were raised about the treatment of the Javanese peasants who were forced to work on the plantations, also as a way to "pay" their taxes. That the colonial system of dual rule lacked a separation of powers was furthermore targeted as grounds for abuse. ${ }^{53}$

Max Havelaar helped to turn the many immoralities associated with the Dutch colonial system into a wider public concern within the Netherlands. ${ }^{54}$ This famous novel was published in 1860 by Multatuli, a pseudonym for Eduard Douwes Dekker, a former Dutch colonial administrator (assistant-resident) of the district of Lebak in Java between 1855 and $1856 .{ }^{55}$ In 1856 he resigned, returned to Europe and wrote Max Havelaar, informed by his own experiences. The book was, in fact, one big attack on a great variety of corrupt practices. Besides addressing that a successful career in the colonial service depended on patronage and favouritism, more importantly Max Havelaar denounced a culture of administrative malpractices and described how an indigenous prince had misused his powers, for he confiscated cattle from the local peasants 
and asked for seigneurial services as a form of taxation, which was officially forbidden as extortion (knevelarij). ${ }^{56}$ Douwes Dekkers saw this as systemic corruption, as it took place on such a frequent scale that the local population lived in misery. That the colonial administrator in the novel sent in official complaints - even to the governor general in Batavia-but did not hear back, was another type of corruption: turning a blind eye towards misuse, even when officially reported. Plurality of norms was a breeding ground here as well: colonial officials had the responsibility to report administrative corruption, but the governor general also had the discretionary power to decide whether or not the complaint would be followed up on if upholding stability, esteem and authority required so. Max Havelaar ended with a plea that citizens of a self-respected Christian nation should no longer tolerate the abuse of the local population by the indigenous aristocrats, a type of argumentation that had been used to legitimise the expansion of colonial control already as early as the eighteenth century.

Max Havelaar was a shock to contemporaries, but neither written nor understood as a plea to end colonial rule. The main results of the publication and accompanying debates were that in the decades thereafter, a new generation of men were inspired to become colonial administrators, ${ }^{57}$ alongside efforts to improve the education of colonial administrators in order to better understand indigenous society and equip them to carry out the so-called "white man's burden". 58 Conservatives in favour of the status quo, including maintaining the Cultivation System, such as minister of Colonial Affairs Johannes Jerphaas Hasselman tried to counter negative sentiments, even by secretly financing the famous journalist Conrad Busket Huet to turn the Java-bode in a pro-Conservative colonial newspaper, leading to a scandal in 1868.59 This "Conservative-intermezzo" in Dutch political history could not prevent the Liberal majority in Dutch Parliament from asking for measures, that led to the termination of the Cultivation System by the 1870s. Besides concerns about diminishing revenues and economic opportunities, the reforms were also framed in moralistic terms. For example, the Agrarian Law (1869) opened uncultivated land for exploitation by entrepreneurs, but land could only be leased and not confiscated to fence private claims. Meanwhile, the Sugar Law (1870) opened up the sugar industry, but issued that peasants could no longer be forced to cultivate sugar. Earlier, the Liberal Minister of Colonial Affairs Franssen van de Putte, himself a former director of a sugar plantation who had returned to the Netherlands as a wealthy man, had 
brought an end to the obligation for the indigenous population to work in communal forests, as well as to corporal punishment by restricting the powers of the local village heads (dessahoofden); their role and behaviour were seen as reasons for many abuses. Additionally, extra bans and penalties on extortion were introduced, and in 1869 an important step in the separation of powers was taken in order to strengthen enforcement of rules, when it was decided to appoint trained jurists to lead local courts, instead of leaving it to administrators. ${ }^{60}$

However, newspapers continued to report abuses: civil servants, both Dutch and indigenous, confiscated cattle for transportation or asked the indigenous peasants to deliver crops and fruits, which in colonial newspapers were labelled as "misuse" and "malpractice", because they were against the "law" and "humanity". ${ }^{61}$ This type of corruption was an especially serious issue when Dutch officials were involved, as this undermined Dutch prestige: the Dutch had to set the example of good government, and only then one could expect indigenous officials to follow-as the colonial newspaper De Locomotief wrote in $1869 .{ }^{62}$ These examples testify that newspapers - even those with a reputation for being criticalexpressed ideas of racial hierarchy, by suggesting the issue of colonial corruption could be solved by upholding "Dutch" legal and humanitarian norms within the context of an indigenous "corrupt feudal society". ${ }^{63}$

\section{“Corrupt Concessions", Growing Unease ANd The Dutch Civilising Discourse}

The end of the Cultivation System was followed by a "Liberal period" that led to increasing private investments and activities. ${ }^{64}$ However, this is not to say that the role of the state in colonial affairs diminishedto the contrary. Entrepreneurs could acquire land from local princes and lower aristocrats for relatively low prices, but only because the colonial state claimed to be the ultimate owner of the land and granted licences to formally legitimate transactions (see also the chapter in this volume on paperwork by Jonathan Saha). Moreover, private agreements between European entrepreneurs and local elites had to be confirmed by the colonial administration in order to become effective. ${ }^{65}$ Next, to control the indentured workers (who were referred to using the derogatory term "coolies" or "koelies" in Dutch during the era) and make profits, the "Coolie Ordinance" gave private companies the right to use force on their own territories. Thus, they were granted a right that is and already at the 
time was, regarded as essential to modern state formation, namely the right to legitimately use force on your territory. The acquisition of land and the right to exploit and control it, including the labourers working on it, were the sources of new accusations of corruption. On the one hand, the process of granting licences came with violations of local rights and was vulnerable to favouritism. On the other hand, once granted the extensive rights given to private entrepreneurs came with very harsh working conditions and exorbitant profits, resulting in public dismay, scandals and investigations. ${ }^{66}$

This type of corruption surrounding concessions was no mere incident: it was at stake in other colonial empires as well, as shown in the contribution to this volume by Didier Guignard; for the Dutch case several examples can be provided. ${ }^{67}$ One such case is the Billiton scandal of 1882 to $1892,{ }^{68}$ which was about an extension of a concession to extract tin ore from the island of Billiton. The original concession was granted to the Billiton company in 1852 for 40 years; in 1882 an extension of another 35 years, starting from 1892, was provided by Governor General Frederick s' Jacob. In the Dutch press and in Dutch Parliament, the agreement was seen as illegal and immoral because Parliament was not consulted and the conditions upon which the extension was granted were way too favourable to the company and its shareholders. Parliament issued an investigative committee, who confirmed the illegality and immorality of the concession forcing the minister of colonial affairs and the governor general to resign. Years of renegotiations followed, during which the Billiton company was also accused of other forms of corruption, such as bribing local officials, ill-treating the Chinese indentured labourers, tolerating opium smuggling, abuse of its taxation and custom rights, as well as misuse of its policing powers. The company argued that many of these issues were inherently related to the harsh local circumstances and to the culture the Chinese kongsies (collaborations between indentured labourers) brought with them. Critical voices, however, blamed the company for neither acting "modern" nor as a "good father" and because of that, endangering Dutch authority and esteem. Some Dutch MPs proposed to publicly exploit the tin mines on Billiton. ${ }^{69}$ Under parliamentary pressure and the threat of nationalisation, in 1892 the company was prepared to accept an extension of the concession that was based on a taxation of 62.5 per cent of the net profit, instead of the 10 per cent agreed in 1882. The company kept its policing powers; in fact, this private 
company needed to act more "governmentally" as some MPs had argued in Parliament. ${ }^{70}$

These, and other examples, not only support the argument that the "nexus between business and expansion has been crucial in the Dutch case", 71 but also make clear how public and private, business and state, economic and political interests were blurred, not so much as a sideeffect, but openly and intendedly. This led to tensions and scandals that were used to adapt or reinstal norms that did not take away the breeding ground for this type of corruption as such. Besides the Billiton scandal, one could point to the ongoing unease and discussions about how colonial lobbyists, including former ministers, tried to prevent the inception of stricter social regulations and corporate taxation in the years around $1900 .^{72}$ Alternatively, the scandal caused by the Deli company that exploited tobacco in Sumatra, and became a synonym to "brutal repression, deceit and maltreatment" of indentured labourers, was backed by the Coolie Ordinance which gave extreme legal powers to companies. These powers included the right to prosecute and sanctionthe poenale sanctie, in force until 1931-in order "to deal" with their workers. $^{73}$ Misuse of these powers also led to the so-called "coolie' scandal" (1903-1905), after an investigation (the Rhemrev report) revealed systematic ill-treatment of labourers on the plantations of Sumatra as well as how entrepreneurs were "protected" by the colonial administration. ${ }^{74}$ Although often framed as incidents by contemporaries, there were recurrent investigations into what were considered exorbitant private revenues and immoral behaviour of companies, which were linked to the deprived position (mindere welvaart) of peasants and workers. ${ }^{75}$

The "Ethical Policy" (ethische politiek) is important to take into account in order to understand the moral disputes and scandals during these years. In 1901, the Ethical Policy was officially proclaimed by Queen Wilhelmina (1898-1948) in her yearly address at the opening of the parliamentary year. There she stated: "As a Christian power, the Netherlands has an obligation ... to suffuse every part of government policy with the consciousness that the Netherlands has a moral obligation to the people of that region". ${ }^{76}$ From a comparative perspective, the Ethical Policy can be considered the Dutch equivalent of the civilising missions that were launched by other imperial powers during this era. According to the advocates of the Ethical Policy, the Dutch did not have a right to exploit, but rather an obligation to develop the colony through investments in education, infrastructure and social policy, which would also 
strengthen the legitimacy of colonial rule. Besides a long-lasting discussion about immoral practices and corruption in the colony, the Ethical Policy was also the result of changing circumstances "at home"; it was announced in the context of social policy established as an answer to the "social question". ${ }^{77}$ The Ethical Policy was supported by socially minded Liberals and Orthodox-Protestants, and even prominent SocialDemocrats such as MP Henri van Kol, who saw the task of the Dutch to be a father educating his children to prepare them for independence. ${ }^{78}$ Although investments in health care and education were complete, the Ethical Policy went hand-in-hand with growing distrust in the local elites. The Orthodox-Protestant Titus Asch van Wijk-Minister of Colonial Affairs in the cabinet of Prime Minister Abraham Kuyper (1901-1905) that launched the Ethical Policy - when discussing the role of the Dutch in exploiting Indonesian Archipelago resources, argued that colonial policy's main aim was "to protect the population from the extortionate practices of their own leaders". ${ }^{79}$

When looking at the training and appointment procedures of colonial officials after 1900, the Ethical Policy and "white man's burden" led to concern with improvement through better understandings of local circumstances, but it did not result in the inclusion of indigenous elite members in the Dutch-controlled colonial administration, because of racially inspired mechanisms of distrust and hierarchy. ${ }^{80}$

In the 1920s and 1930s, financial reasons and disappointments about the results of the policy, including that better education contributed to the creation of a self-aware group of indigenous men such as Sukarno and Hatta who asked for independence of Indonesia, led to the abandonment of the Ethical Policy. In fact, the colonial state turned into something that increasingly resembled a police state, including an emphasis on public order and moral purity, which led to actions and corruption scandals that were seen as arbitrary and racially driven. ${ }^{81}$

\section{Conclusion: On the Persistence of Corruption in a (Post-)Colonial Context}

Throughout the nineteenth century, colonial corruption was an issue of recurrent debate and stimulant to reforms. The many examples of (campaigns against) corruption, lead to the question: how to understand the persistence of colonial corruption? The historiography of corruption in Europe has pointed to the role of plurality and competition of norms as 
a breeding ground for corruption. ${ }^{82}$ Clearly, this is also relevant to understanding colonial corruption. When from around 1800 "bureaucratic", "Dutch" or "modern" norms were introduced-for example by turning former representatives of the VOC and indigenous elites into salaried bureaucrats who had to represent and serve state interests-strikingly, this went alongside strengthening a system of dual rule that, again, allowed for privileges for certain groups and individuals. Furthermore, bureaucratic changes were also half-heartedly taken, or deliberately abandoned after a while, for economic and financial reasons. That in the colonial context, economy and politics or entrepreneurial and state interests were structurally entangled was another reason for competition of norms. The latter was undergirded by policies which intentionally assigned public tasks to different groups: administration and ultimately arbiter authority to the Dutch, tax farming and dual rule supporting bureaucrats, respectively, to leading Chinese and indigenous aristocrats and indentured labour to indigenous peasants and Chinese "koelies". Finally, the existence of varied and competing norms was the result of an imperial context in which norms that were established in the "motherland", such as the abolishment of tax farming or the separation of powers, were not upheld in the colony. Thus, as conflicting norms were no mere incidents, but structural to colonial rule, it is not surprising that corruption was structurally evident.

To better understand the persistence of corruption in modern society, from a meta-level perspective, the European historiography has pointed to the mythical or false assumptions underlying ideas about modernitysuch as the problematic nature of the concept of (linear) progress, as well as the multiple forms (understandings of) "modernity" can take and the impossibility to completely separate the public and private, or to reach into the ideal situation of the corruption-free modern society. ${ }^{83}$ Additionally, from a macro-level perspective, the implementation of supposedly "good" and "just" modern institutions-such as impersonal and rational bureaucratic rule-has had paradoxical consequences as they were also a breeding ground for new forms of corruption-for example, bureaucratic corruption. From a micro-level perspective, the above insights are supported by the great number of scandals and cases of misuse of public power that have been located by historians, again falsifying the notion that corruption was solely a problem of early modern societies, or incidental in modern and contemporary history. Emphasising the persistence of corruption should not be confused with the denial of change and 
difference in history-certain (and serious) forms of corruption did disappear-but to make us sensitive to the fact that there is no automatic relationship between less corruption and the modern era.

For a better understanding of colonial corruption in the nineteenth and early twentieth centuries, we also have to include the historiography on colonialism and imperialism. Although often not about colonial corruption very specifically, it draws our attention to the intentional character of colonial corruption, either in the form of a structural lack of dedication to set and maintain norms, or by creating difference "through corruption" in order to rule and instal awe. ${ }^{84}$ Concerning the first issue, European colonialism was "empire on the cheap", as Frederick Cooper argues: there was a constant lack of dedication in providing the necessary financial resources and men (e.g. administrators, jurists, policemen, doctors) to introduce and maintain "modern" standards. ${ }^{85}$ The earlier discussed example of the Dutch decision in 1869 to strengthen the separation of powers by sending trained jurists to the Dutch East Indies to lead courtrooms (landraden) is telling. It would have required a number of jurists the government was never willing to recruit and pay for, therefore even by Indonesian independence in 1945, no separation of powers existed in many parts of the archipelago. ${ }^{86}$

Concerning the issue of creating difference "through corruption", it is insightful to make use of how the paradoxes of "modernity" have been understood in new imperial and (post-)colonial historiography. ${ }^{87}$ Colonial corruption can be seen as "a way of talking about the world"-an important part of the "language of modernity". 88 Debates on corruption can be studied and seen as concrete examples of the discourses on "modernity" and "modernisation" and their consequences: colonial corruption was used both as a practice and as a rhetorical act of denunciation to make powerful claims and counterclaims in the name of cultural, political and economic modernisation. ${ }^{89}$ To make sense of what was at stake-or to incorporate it into the language of modernity-contemporary representatives of colonial rule recurrently portrayed corruption as the outcome of the "traditional", "uncivilised", "feudal" or "barbarian" circumstances, and thus fighting and solving corruption as a modern, rational and Dutch or European concern. According to this narrative of self-legitimisation, the colonial administration tried to do whatever it could do to prevent and stop injustices, while at the same time labelling corruption as an inherent part of the "Other". Nonetheless, this was a tricky strategy, as is 
also evident in the Dutch case. Colonial corruption could only be acceptable for a while, but abnormal in terms of ideas about the future. Not surprisingly, quite early on there was talk of a link between colonial rule and colonial corruption, instead of one between colonial rule and good government. Maybe even less surprising, and as another type of historical evidence, after a while representatives of the colonial administration began to lose their faith in civilisational ideology. Institutions, and their staff, which had been established to investigate and curb abuse of powers (for example, health and labour inspections at plantations), left their offices disappointed or began to point at the necessity of harsh sanctions that strikingly came with modern colonial exploitation, but were presented as a way to deal with specific local circumstances. ${ }^{90}$

Additionally, new imperial history—as does global history-makes us sensitive to understanding colonial corruption and responses to it as part of an entangled history. Anticorruption measures were often inspired by circumstances in the motherland and the colony alike; see the period of denouncing Ancien Régime corruption and promoting reform in the years around 1800, or responses to the "social question" and the need to check private businesses in the years around 1900. Keeping the problem of colonial corruption on the agenda could also have served to redirect attention from political tensions at home, or served a type of nationalism based on assumptions of Dutch moral superiority.

This contribution was about the Dutch-Indonesian relationship, but the role colonial corruption played in this case is not unique. ${ }^{91}$ Guignard has shown the existence of corrupt practices for French Algeriai.e. misuse of power, electoral fraud, illegal appropriation of land and resources, the dubious granting of concessions, arbitrary rule and judicial and administrative ambiguity when misuses were reported-as well as how the denunciation or silencing of corruption depended on political circumstances in the motherland. ${ }^{92}$ Saha has shown with the case of colonial Myanmar around the year 1900, how corruption was framed in the press, administration and political scene as a local, traditional and "Oriental" practice that could hardly be rooted out. At the same time, British officials gave room to local subordinates, often non-white and non-British, to abuse their position so that the British could reprimand or prosecute subordinates in order to show that the colonial administration did its best to curb corruption. However, just as often, petitions about misuse were neglected if they were regarded a danger to colonial rule. Thus, according 
to Saha, corruption-in these different forms-was "everyday" to colonial rule because "[c]orruption was performative. It was often through acts of malfeasance and misconduct that the state was manifested and experienced in everyday life". 93

Informed by the above, we need to rethink examples of practices and debates about corruption and their responses in the context of colonial empires; they were occurring in a great variety and were no mere incidents. Moreover, they might have been among the most useful to create and cement difference and asymmetrical power relations: the colony was corrupt, the metropole was not, hence colonial elites were "allowed" to interfere and set norms in the colony. This explains why the colonial administrations dealt with the anxiety of corruption rather softly: there was no desire to completely eliminate corruption because its existence of a systemic problem legitimised colonial rule. ${ }^{94}$ Additionally, to find legitimacy for colonial rule, the imperial government itself played a significant role in the creation and reproduction of "local" corruption, which needed to be countered and curbed with "modern" means. In other words, colonial rule was one great anticorruption project that would, could and should never be finished. ${ }^{95}$

Understanding colonial rule as a process of creating outcomes that had to be curbed by anticorruption projects, is a perspective that could be useful for further research into the entangled history of (post-)colonial "spaces of morality". 96 For the long nineteenth century, there is much more to say about the Indonesian perspective. For example, how did the variety of indigenous actors understand, contribute to or counter the "corrupt colony" during the eras of the Cultivation System or the Ethical Policy? Also, what was the role of denouncing corrupt colonialism for Indonesian nationalists working towards independence from the 1910s onwards? ${ }^{97}$ Moreover, how was their understanding rooted in an entangled history? Take, for example, Sukarno's critique on colonialism, ${ }^{98}$ the criticism against colonial rule coincided criticism against indigenous feudalism and the aristocracy in connection to luxury and decadence. ${ }^{99}$ Or references in newspapers in which the ill-treatment of the population that were, in "modern" style, linked to the return to a corrupt past. In the Soerabaiasch Handelsblad in 1934, Joesoef Jahja Nasoetion-the editor of the paper Persatoen Indonesia-was accused of spreading hate against the Dutch Indies Government (the haatzaai artikelen). In an article on the conditions of the Bangka local government, he mentioned that the government wanted to destroy the economy 
of the local people, kill the Partindo (a non-cooperative political party), keep the people of Bangka ignorant and return to a time of "arbitrary rule and corruption". ${ }^{100}$ During the struggle for independence and in the first years of independence in the late 1940s and early 1950s, the Netherlands, the Dutch Indies and the Indonesian Republic labelled each other's governments as being corrupt. On the other hand, Indonesian attempts to develop the country in the 1950s were inspired by indigenous political traditions, colonial understandings of corruption and Dutch bureaucratic expertise - as well as US modernisation theories. ${ }^{101}$ Strikingly, in the 1950s, the Indonesian military installed a series of anticorruption measures which eventually cleared the way for a gradual military takeover of the state. After the military takeover, the Dutch-Indonesian relationship changed again, and an Inter-Governmental Group on Indonesia (IGGI) was installed to streamline and coordinate the relationship under the label of development aid. Development aid ideally would bring prosperity and end corruption, but it also led to activities that became associated with the structural existence of KKN (Korupsi, Kolusi, Nepotisme; Corruption, Collusion, Nepotism). ${ }^{102}$ Finally, with the help of an historical approach of corruption, the origins of contemporary understandings can be reinvestigated-such as contemporary rankings which stress that many former colonies are among the most corrupt and that have a great impact on stereotyping and foreign investments. ${ }^{103}$ What are the historical legacies and dynamics behind these indices? Research into this topic could also shed more light on the link between colonialism and today's corruption - a relationship quite often suggested but only incidentally researched 104 - and to get beyond "colonial determinism", in which the colonial past is an umbrella source to explain the present. ${ }^{105}$

Acknowledgements I am very grateful to the anonymous reviewers consulted by Palgrave, as well as to Susan Legêne, Alicia Schrikker, Farabi Fakih, Maarten Manse and to the participants of the conference "The Corrupt Colony?" (Amsterdam January 2019) for their comments on earlier versions of this text. Additionally, to Bel Parnell for her corrections. Finally, I would like to thank CLUE+ the interfaculty Research Institute for Culture, Cognition, History and Heritage of the Vrije Universiteit Amsterdam for a grant that made it possible to publish this chapter open access. 


\section{Notes}

1. Jan Luiten van Zanden and Daan Marks, An Economic History of Indonesia 1800-2010 (London: Routledge, 2012), 30, 31, 72, 107 and 113; Ewout Frankema and Frans Buelens, Colonial Exploitation and Economic Development. The Belgian Congo and the Netherlands Indies Compared (London: Routledge, 2013), 122-124.

2. Kees Briët, Het proces van Rijck van Prehn en Johannes Wilhelmus Winter. Een bijzondere zaak voor het Hooggerechtshof van Nederlands-Indië in 1820 (Hilversum: Verloren, 2012).

3. Alicia Schrikker, "Restoration in Java 1815-1830: A Review," BMGNLow Countries Historical Review 130, no. 4 (2015): 134 and 135; Chris Niertrasz, In the shadow of the company: The Dutch East India Company and Its' Servants in the Period of Its' Decline 1740-1796 (Leiden: Brill, 2012).

4. Ronald Kroeze, "Dutch Political Modernization and the Billiton Case (1882-1892). The Usefulness of a Neoclassical Contextual Approach to Corruption," in Integration, Legitimation, Koruption. Politische Patronage in Früher Neuzeit und Moderne, eds. Ronald G. Asch, Birgit Emich and Jens I. Engels (Frankfurt and New York: Peter Lang, 2011), 285-307.

5. Marieke Bloembergen, De geschiedenis van de politie in Nederlands-Indië: uit zorg en angst (Amsterdam: Boom; Leiden: KITLV Uitgeverij, 2009).

6. Multatuli [Eduard Douwes Dekker], Max Havelaar. Of de Koffiveilingen der Nederlandse Handel-maatschappy (Amsterdam: Antheneum-Polak \& Van Gennep, 2011 [1860]).

7. Willem F. Wertheim, "Corruptie," in Geld en geweten. Een bundel opstellen over anderehalve eeuw Nederlands bestuur in de Indonesische archipel, deel 2: het tijdvak tussen 1900-1942, ed. C. Fasseur (Den Haag: Martinus Nijhof, 1980), 213-221. Originally published as W.F. Wertheim, "Corruptie als sociologisch studieobject," in Corruptie, eds. Willen F. Wertheim and H.J. Brasz (Assen: Van Gorcum, 1961): 21-30.

8. Ibid., 219.

9. Schrikker, "Restoration in Java," 143. Schrikker points to the relevance of researching corruption in a colonial setting for understanding changing normative orders and institutional practices. She refers to "the growing literature on corruption, scandal and public morality in the Netherlands".

10. The project "Colonial normativity: Corruption and difference in colonial and postcolonial histories of empire and nations: an entangled history of the Netherlands and Indonesia 1870s-2010s" is designed as such a joint programme. It was provided funding by the Dutch Research Council (NWO) in 2019 and will be executed by historians of the Vrije 
Universiteit Amsterdam and UGM Yogyakarta, with the advice of their international academic networks and several relevant NGOs. See: "Colonial normativity: Corruption and difference in colonial and postcolonial histories of empire and nations: an entangled history of the Netherlands and Indonesia 1870s-2010s", CLUE + VU, accessed July 20, 2020, https://www.clue.vu.nl/en/projects/colonial-normativity/index.aspx.

11. Ronald Kroeze, André Vitória and Guy Geltner, eds, Anticorruption in History: From Antiquity to the Modern Era (Oxford: Oxford University Press, 2018).

12. For the British case, Dirks has shown similar trends in accusations against the corrupt Governor Warren Hastings. Hastings represented a long tradition of colonial rule in which self-enrichment played a crucial role, and although the attacks on Hastings were framed as anticorruption measures that served the general interest, they were also informed by personal grievances and factional strife. Moreover, in the long run, the attacks served to promote more state control over the revenues of India while the enrichment by the British rulers and the extraction of local resources continued. Nicolas B. Dirks, The Scandal of Empire: India and the Creation of Imperial Britain (Cambridge, MA: Harvard University Press, 2006).

13. Hillard von Thiessen, "Korrupte Gesandte? Konkurrierende Normen in Der Diplomatie Der Frühen Neuzeit," in Korruption. Historische Annäherungen an Eine Grundfigur Politischer Kommunikation, eds. Niels Grüne and Simona Slanička (Göttingen: Vandenhoeck \& Ruprecht, 2010), 205-220; Hillard von Thiessen, "Korruption Und Normenkonkurrenz. Zur Funktion Und Wirkung Von Korruptionsvorwürfen Gegen Die Günstling-Minister Lerma Und Buckingham in Spanien Und England Im Frühen 17. Jahrhundert," in GeldGeschenke-Politik: Korruption Im Neuzeitlichen Europa, eds. Jens Ivo Engels, Andreas Fahrmeir and Alexander Nützenadel (Munchen: Oldenbourg, 2009), 91-120.

14. Toon Kerkhoff, Ronald Kroeze and Pieter Wagenaar, "Corruption and the Rise of Modern Politics in Europe in the Eighteenth and Nineteenth Centuries. A Comparison between France, the Netherlands, Germany and England-Introduction," Journal for Modern European History 11 (2013): 19-30.

15. Remco Raben, "A New Dutch Imperial History?: Perambulations in a Prospective Field," BMGN-Low Countries Historical Review 128, no. 1 (2013): 5-30; Marieke Bloembergen and Vincent Kuitenbrouwer, eds., "A New Dutch Imperial History Connecting Dutch and Overseas Pasts," BMGN-Low Countries Historical Review (special issue) 128, no. $1(2013): 1-5$.

16. Raben, “New Dutch Imperial History?," 10. 
17. Kroeze, Vitória and Geltner, Anticorruption in History; Jens Ivo Engels, Die Geschichte der Korruption. Von der Frühen Neuzeit bis 20. Jahrhundert (Frankfurt: Fischer Verlag, 2014); F. Monier, O. Dard and A. Fahrmeir, eds., Scandales et corruption à l'époque contemporaine (Paris: Armand Colin, 2014).

18. Cesare Mattina, Frédéric Monier, Olivier Dard and Jens Ivo Engels, eds., Dénoncer la corruption: Chevaliers blancs, pamphlétaires et promoteurs de la transparence à l'époque contemporaine (Paris: Demopolis, 2018).

19. Jens Ivo Engels, "Corruption and Anticorruption in the Era of Modernity and Beyond," in Anticorruption in History: From Antiquity to the Modern Era, eds. Ronald Kroeze, André Vitória and Guy Geltner (Oxford: Oxford University Press, 2019), 167-180.

20. See Engels, Die Geschichte der Korruption; Toon Kerkhoff, Ronald Kroeze, Pieter Wagenaar, and Michel Hoenderboom, A History of Dutch Corruption and Public Morality (1648-1940) (Newcastle upon Tyne: Cambridge Scholars Publishers, 2020).

21. Toon Kerkhoff, "Hidden Morals. Explicit Scandals: Public Values and Political Corruption in the Netherlands (1748-1813)" (PhD diss., Universiteit Leiden, 2012); James Kennedy and Ronald Kroeze, "The Paradox of 'A High Standard of Public Honesty': A Long-Term Perspective on Dutch History," in Anticorruption in History. From Antiquity to the Modern Era, eds. Ronald Kroeze, André Vitória and Guy Geltner (Oxford: Oxford University Press, 2019), 211-224.

22. René Koekkoek, "Envisioning the Dutch Imperial Nation-State in the Age of Revolutions," in The Dutch Empire Between Ideas and Practice, 1600-2000, eds. René Koekkoek, Anne-Isabelle Richard and Arthur Weststeijn (Cambridge: Cambridge University Press, 2019), 135-157.

23. As cited in Piet Emmer and Jos Gommans, Rijk aan de Rand van de Wereld: de geschiedenis van Nederland overzee 1600-1800 (Amsterdam: Bakker, 2012), 139.

24. Van Zanden and Marks, An Economic History of Indonesia, 30 and 31. See also: Nierstrasz, In the shadow of the company.

25. Hui Kian Kwee has shown how the rules of the "game" were set by the VOC but that the economic success at Java's North-East coast was based on a "synergy" between VOC representatives and various local elites competing and cooperating for opportunities and power. See: Hui Kian Kwee, The Political Economy of Java's Northeast Coast. c. 17401800: Elite Synergy (Leiden: Brill, 2006); Hui Kian Kwee, "Chinese Economic Dominance in Southeast Asia: A Longue Durée Perspective," Comparative Studies in Society and History 55, no.l (January 2013): 5-34.

26. Schrikker, "Restoration in Java," 134; see also Koh Keng We, who put it this way: "a period of fragmentation and decline from the perspective of Dutch Hegemony ... this was also a period of opportunity and 
adjustment for local rulers and elites". Koh Keng We, "Review-Article: Re-thinking the Colonial Transition: The Case of Java's Northeast Coast 1740-1850," Journal of Southeast Asian Studies 38, no. 2 (June 2007): 386.

27. Schrikker, "Restoration in Java," 135.

28. Engels, Der Geschichte der Korruption.

29. Eelkje Poortinga, De scheiding tussen publiek- en privaatrecht bij Johan Rudolph Thorbecke (1798-1872) (Nijmegen: Ars Aequi Libri, 1987).

30. Michael Walzer, "Liberalism and the Art of Separation," Political Theory 12, no. 3 (August 1984): 315-317.

31. André Steiner, "Corruption in an Anticorruption State? East Germany Under Communist Rule," in Anticorruption in History. From Antiquity to the Modern Era, eds. Ronald Kroeze, André Vitória and Guy Geltner (Oxford: Oxford University Press, 2018), 293-304.

32. For a critical reflection, inspired by postcolonial thinking, see: Amy Allen, The End of Progress. Decolonizing the Normative Foundations of Critical Theory (New York: Columbia University Press, 2016).

33. William. D. Rubinstein, "The End of 'Old Corruption' in Britain 17801860," Past and Present 101, no. 1 (1983): 55-86.

34. Mary Lindeman, "Dirty Politics or 'Harmonie'? Defining Corruption in Early Modern Amsterdam and Hamburg," Journal of Social History 45, no. 3 (2012): 583 and 584 .

35. Ibid.

36. Chris te Lintum, Een eeuw van vooruitgang, 1813-1913 (Zutphen: Thieme, 1913), 165; Earlier, James Kennedy and I pointed to this development in Kennedy and Kroeze, "The Paradox.".

37. Compare the opening sentence of L. P. Hartley in The Go-Between (London: Hamish Hamilton, 1953): "The Past Is a Foreign Country; They Do Things Differently There"; and, of course, on "Othering" and "Orientalism", see Edward Said, Orientalism (London: Routledge and Kegan Paul, 1978).

38. Susan Legêne, De bagage van Blomboff en Van Breugel: Japan, Java, Tripoli en Suriname in de negentiende-eeuwse Nederlandse cultuur van het imperialisme (Amsterdam: Koninklijk Instituut voor de Tropen, 1998).

39. Beatrice de Graaf, Tegen de terreur. Hoe Europa veilig werd na Napoleon (Amsterdam: Prometheus, 2018).

40. Schrikker, "Restoration in Java," 144.

41. Briët, Het proces.

42. Peter Carey, "Revolutionary Europe and the Destruction of Java's Old Order, 1809-1830", in: David Armitage and Sanjay Subrahmanyam (eds.), The Age of Revolutions in Global Context, c. 1760-1840 (Basingstoke: Palgrave Macmillan, 2009), 167-188. 
43. Angelie Sens, De kolonieman: Johannes van den Bosch (1780-1844), volksverheffer in naam van de koning (Amsterdam: Uitgeverij Balans, 2019).

44. Jur van Goor, as cited in Schrikker, "Restoration in Java," 135.

45. Van Zanden and Marks, Economic History of Indonesia, 47-55.

46. On the existence of different forms of slavery, even after the official abolition of enslavement, see Peter Boomgaard, "Human Capital, Slavery and Low Rates of Economic and Population Growth in Indonesia, 1600-1910," Slavery \& Abolition 24, no. 2 (2003): 83-96; on forced labour and the Cultivation System see: Ulbe Bosma, "The Discourse on Free Labor and the Forced Cultivation System: The Contradictory Consequences of the Abolition of the Slave Trade in Colonial Java, 1811-1870," in Humanitarian Intervention and Changing Labor Relations: The Long-Term Consequences of the Abolition of the Slave Trade, ed. Marcel van der Linden (Leiden and Boston: Brill, 2011).

47. Van Zanden and Marks, Economic History of Indonesia, 46-72.

48. Sanne Ravensbergen, "Rule of Lawyers: Liberalism and Colonial Judges in Nineteenth-Century Java," in The Dutch Empire Between Ideas and Practice, 1600-2000, eds. René Koekkoek, Anne-Isabelle Richard and Arthur Weststeijn (Cambridge: Cambridge University Press, 2019), 163.

49. Ibid., 165.

50. Kerkhoff, Hidden Morals, 84-89, 117 and 132.

51. With thanks to Maarten Manse, who is finishing a $\mathrm{PhD}$ thesis on taxation in the Dutch East Indies. See also Abdul Wahid, "In the shadow of opium. Tax farming and the political economy of colonial extraction in Java, 1807-1911," in Colonial Exploitation and Economic Development. The Belgian Congo and the Netherlands Indies compared, eds. Ewout Frankema and Frans Buelens (London and New York: Routledge, 2013).

52. David Henley, "Credit and Debt in Indonesian History: An Introduction," in Credit \& Debt in Indonesia, 860-1930: From Peonage to Pawnshop, from Kongsi to Cooperative, eds. David Henley and Peter Boomgaard (Singapore: Institute of Southeast Asian Studies/Leiden: KITLV Press, 2009), 11-13; Hui Kian Kwee, "Chinese Economic Dominance in Southeast Asia: A Longue Duree Perspective," Society and History 55, no.l (January 2013): 5-34.

53. Ravensbergen, "Liberalism and Colonial Judges," 165 and 166.

54. Raben, "New Imperial History," 26.

55. Multatuli, Max Havelaar.

56. Tom Phijffer, Het gelijk van Multatuli het handelen van Eduard Douwes Dekker in rechtshistorisch perspectief (Amsterdam: Uitgeverij Bas Lubberhuizen, 2000).

57. Wim van den Doel, Het Rijk van Insulinde: opkomst en ondergang van een Nederlandse kolonie (Amsterdam: Prometheus, 1996) 70, 103 and 104. 
58. Cees Fasseur, De Indologen. Ambtenaren voor de Oost 1825-1950, 3rd ed. (Amsterdam: Aula, 2003), 384-389.

59. G. Termorshuizen, “Busken Huet en 'het geval Hasselman' na honderd jaar," De Gids 132 (1969): 139.

60. Ravensbergen, "Liberalism and Colonial Judges," 165 and 166.

61. "Beschermende bepalingen tegen knevelarij," De Locomotief, September 29, 1869, front page.

62. Ibid.

63. Heather Sutherland, The Making of a Bureaucratic Elite: The Colonial Transformation of the Javanese Priyayi (Singapore: Heinemann, 1979), vii.

64. Thomas Lindblad, Foreign Investment in South East Asia (London: Palgrave, 1998) 47 and 48; Van Zanden and Marks, An Economic History of Indonesia, 73.

65. Ibid., 83 .

66. Ulbe Bosma, The Sugar Plantation in India and Indonesia: Industrial Production, 1770-2010 (Cambridge: Cambridge University Press, 2013); Adrian Vickers, A History of Modern Indonesia (Cambridge: Cambridge University Press, 2005), 16-19; Jan Breman, Koelies, planters en koloniale politiek. Het arbeidsregime op de grootlandbouwondernemingen aan Sumatra's oostkust in het begin van de twintigste eeuw (Dordrecht: Foris, 1987).

67. One could also take the "Djambi-scandal" of 1921, which was about the favourable and secret conditions upon which concessions were grantedin this case an oil concession to Royal Dutch Shell. The Communist W. Ravesteijn published Het Djambi-schandaal in 1921, which led to questions to be asked in Parliament. In this pamphlet, the following was argued: The Minister of Colonial Affairs and the director of Royal Dutch Shell had secretly cooperated to prevent Standard Oil from obtaining a concession to explore oil fields in the Dutch East Indies. The director of Royal Dutch Shell, Hendrikus Colijn, was also a famous politician and several times minister and prime minister. Communist MPs denounced the corrupt relations between state and big business. See also: Wertheim, "Corruptie", 220.

68. About this case, I published earlier and in more detail, see: Kroeze, "The Billiton Case (1882-1892)".

69. Handelingen van de Staten Generaal der Tweede Kamer (Minutes of the Second Chamber of Dutch Parliament, HTK) May 20, 1892, 1039.

70. Ibid., 1024. Today, one can find a quote of the Billiton Company on their corporate website reading: "Since 1851, we've been developing and contributing to industry, communities and economies around the world." "Our history," Our approach, BHP Billiton, accessed September 24, 2019, https://www.bhp.com/our-approach/our-history. 
71. Raben, "New Imperial History?," 10: "As a result, Dutch colonialism has always been dominated by business interests, whether by monopolising trading companies, absentee plantation entrepreneurs, government exploitation or conglomerates of protected private enterprises. The nexus between business and expansion has been crucial in the Dutch case".

72. Jan Breman, "Het beest aan banden? De koloniale geest aan het begin van de twintigste eeuw," in Bijdragen tot de Taal-, Land-en Volkenkunde 144, no. 1 (1988): 19-43; Arjan Taselaar, De Nederlandse koloniale lobby: ondernemers en de Indische politiek, 1914-1940 (Leiden: Research School CNWS, School of Asian, African and Amerindian Studies, 1998).

73. These are the words of Howard W. Dick and Vincent J. H. Houben, The Emergence of a National Economy. An Economic History of Indonesia, 1800-2000 (Honolulu: University of Hawai'i Press, 2002), 103.

74. The Rhemrev report is printed and discussed in Breman, Koelies, planters en koloniale politiek. At the time, the report caused debate and led to new accusations, see for example: J. F. Dijkstra, De corruptie in de Nederlandsch-Indische ambtenaarswereld, of: Mr. Rhemrev als regeeringscommissaris door J.F. Dijkstra, Planter (Rotterdam: Masereeuw \& Bouten, 1906). See also: Breman, "Het beest aan banden?”; Wertheim, "Corruptie", 216.

75. Breman, "Het beest aan banden?".

76. Elsbeth Locher Scholten, Sumatran Sultanate and Colonial State: Jambi and the Rise of Dutch Imperialism, 1830-1907, Studies on Southeast Asia (Ithaca: Cornell University, 2004), 208.

77. Berteke Waaldijk and Susan Legêne, "Ethische politiek in Nederland. Cultureel burgerschap tussen overheersing, opvoeding en afscheid," in Het koloniale beschavingsoffensief. Wegen naar het nieuwe Indië 18901950, eds. Marieke Bloembergen and Remco Raben (Leiden: KITLV Uitgeverij, 2009), 187-216.

78. Cees Fasseur, "Nederland en het Indonesische nationalisme. De balans nog eens opgemaakt," BMGN- Low Countries Historical Review 99, no. l (1984): 28 and 29, note 2; Ibid., 29: "Vergelijk de benadering van het koloniale vraagstuk in het door H.H. van Kol opgestelde ontwerpprogram van de SDAP voor de koloniale politiek (1901): 'Het behoud onzer koloniën is geen recht maar een plicht geworden. Wij zijn de voogden geworden dier millioenen, wier lot in onze hand is gesteld, (...) door een rechtvaardig en eerlijk bestuur moeten wij hun vertrouwen winnen, hunne welvaart bevorderen... wij moeten het kind opvoeden tot een man. En eenmaal man geworden, zal de Inlander onzer OostIndische koloniën op eigen beenen kunnen staan, de volwassene zal geen steun meer nodig hebben, de rijp geworden vrucht zal afvallen van den boom. Dan, maar ook eerst dan, is het uur zijner volledige autonomie geslagen, dan is onze tijd voorbij, onze taak volbracht..."”. 
79. Locher Scholten, Sumatran Sultanate, 208.

80. Fasseur, De Indologen, 384-388.

81. Bloembergen, Geschiedenis van de politie.

82. Von Thiessen, Korruption und Normenkonkurrenz, 94-98; Von Thiessen, "Korrupte Gesandte?"; Kerkhoff, Kroeze, Wagenaar and Hoenderboom, A History of Dutch Corruption.

83. Engels, "Corruption and Anticorruption"; Dirk Tänzler, K. Maras, and A. Giannakopoulos, "The German Myth of a Corruption-Free Modern Country," in eds. Dirk Tänzler, K. Maras and A. Giannakopoulos, The Social Construction of Corruption in Europe (Surrey: Ashgate, 2012), 87-105; Ronald Kroeze, "The Rediscovery of Corruption in Western Democracies," in Corruption and Governmental Legitimacy: A Twenty-First Century Perspective, eds. Jonathan Mendilow and Ilan Peleg (Lanham: Rowman and Littlefield Publishers, 2016). For a critical and postcolonial analysis of progress see: Allen, The end of progress.

84. Frederic Cooper defines "empire" first, as "...a political unit that is large, expansionist (or with memories of an expansionist past), and which reproduces differentiation and inequality among people it incorporates. (...) An empire-state is a structure that reproduces distinctions among collectivities while subordinating them to a greater or lesser degree to the ruling authority". Second, empire concerns "the making and policing of boundaries, the design of systems of punishment and discipline, the attempt to install awe as well as a sense of belonging in diverse populations". Frederick Cooper, Colonialism in Question. Theory, Knowledge, History (Berkeley, CA, Los Angeles and London: University of California Press, 2005), 7 and 30; On imperialism and the politics of difference see also Jane Burbank and Frederick Cooper, Empires in World History: Power and the Politics of Difference (Princeton, NJ: Princeton University Press, 2010).

85. Ibid., 157. The full quote reads: "Colonial rule was empire on the cheap, creating a patchwork of economic exploitation rather than a systematic transformation, ruling through an often ossified system of "tribal" authority rather than trying to create the docile individual subjects of supposedly modern governmentality".

86. Ravensbergen, "Liberalism and Colonial Judges," 165 and 166.

87. Compare: Colonialism in Question, 149, where Cooper emphasises the "ambivalence" of modern colonial policy; See also Dipesh Chakrabarty, Provincializing Europe: Postcolonial Thought and Historical Difference. (Princeton: Princeton University Press, 2000); Allen, The End of Progress; Antoinette. M. Burton, ed., "Introduction: The Unfinished Business of Colonial Modernities," in Gender, Sexuality, and Colonial Modernities (London: Routledge, 1999): 1-16. 
88. Cooper, Colonialism in Question, 114 and 146. For Cooper, modernisation in the end is about "forward-looking" and a systematic focus on reorganisation of economy and labour, as well as living conditions in cities, industrialisation and urbanisation. It is about "a package of covarying characteristics as markers of progress on the road from stultifying tradition to dynamic modernity".

89. Ibid., 147.

90. Breman, "Het beest aan banden?," 28.

91. Strikingly, in 1948, J.S. Furnival-in Colonial policy and practice. A comparative study of Burma and Netherlands India (Cambridge: Cambridge University Press, 1948), 269-argued that colonial Burma was more corrupt than colonial Indonesia, concerning the latter corruption was "practically unknown". As cited in: Wertheim, "Corruptie", 217. Wertheim himself is not enterally convinced. He suggests that more attention was paid to the problem of corruption in colonial Myanmar than in colonial Indonesia, and the harder one looks, the more one finds (and vice versa).

92. Didier Guignard, L'Abus de pouvoir dans l'Algérie coloniale (1880-1914). Visibilité et singularité. (Nanterre: Presses universitaires de Paris Ouest, 2010).

93. Jonathan Saha, Law, Disorder and the Colonial State. Corruption in Burma ca. 1900 (Basingstoke: Palgrave Macmillan, 2013), 5 and 127.

94. Compare ibid., 9.

95. Compare Burton, "The Unfinished Business of Colonial Modernities.".

96. Compare Raben, "New Dutch Imperial History?," 25.

97. Wertheim does mention this topic but states that Indonesian nationalists did not seriously use accusations of corruption as a political weapon to undermine colonialism, suggesting that corruption was not that big of a problem. However, his analysis is brief and his definition of corruption ambivalent. All the more reason for further research into this topic. Werthem, "Corruptie", 218.

98. His plea was published with the title Indonesia klaagt aan! Pleitrede voor de landraad te Bandoeng gehouden op 2 december 1930, gehouden door ir Soekarno (Amsterdam: Arbeiderspers, 1931) and contains references to corruption going back to the VOC. The text is available via: https:// wvi.antenna.nl/nl/ika/index.html.

99. Exposed by people like Hatta and Kartosuwirjo (the founder of the Darul Islam-Indonesian Islamic State) in Indonesian language newspapers, for instance in Fajar Asia, on the lifestyle of the aristocracies, such as the Sunan of Surakarta. I would like to thank Dr. Farabi Fakih for these suggestions.

100. Soerabaijasch Handelsblad, February 27, 1934: "de Regeering wil de oude toestanden doen terugkeeren, waardoor de ambtenaren naar willekeur kunnen handelen en corruptie weer mogelijk wordt". 
101. Farabi Fakih, "The Rise of the Managerial State in Indonesia. Institutional Transition During the Early Independence Period" (PhD diss., Universiteit Leiden, 2014), 175 and 179.

102. Bambang Purwanto, "Entertain People, Accumulate Capital: Indonesian Military Entrepreneurship in the 1950s and 1960s," in Promises and Predicaments: Trade and Entrepreneurship in Colonial and Independent Indonesia in the 19th and 20th Centuries, eds. Alicia Schrikker and Jeroen Touwen (Singapore: NUS Press, 2015): 151-162; Bambang Purwanto, "Economic Decolonization and the Rise of Indonesian Military Business," in Indonesian Economic Decolonization in Regional Perspective, eds. Thomas Lindblad and Peter Post (Leiden: KITLV Press, 2009): 39-58.

103. Staffan Andersson and Paul Heywood, "The Politics of Perception: Use and Abuse of Transparency International's Approach to Measuring Corruption.” Political Studies 57, no. 4 (2009): 746-767; A.T. Paul, "Korruption als Europaische Erbe?." Geld-Geschenke-Politik: Korruption Im Neuzeitlichen Europa. Historisch Zeitschrift, eds. Jens Ivo Engels, Andreas Fahrmeir and Alexander Nützenadel (Munchen: Oldenbourg, 2009): 275-306.

104. For the Dutch-Indonesian relationship the question is sometimes raised but not really discussed. For the British-Nigerian relationship there seems to be a more lively debate about corruption and colonialism. Hadassah Egbedi, “By ignoring corruption's colonial roots, Cameron's summit was destined to fail," The Guardian, May 13, 2016, https://www.theguardian.com/world/2016/may/13/ignoringcorruptions-colonial-roots-camerons-summit-was-destined-to-fail; Steven Pierce, "Looking Like a State: Colonialism and the Discourse of Corruption in Northern Nigeria", Comparative Studies in Society and History 48, no. 4 (2006): 887-914; Luis Angeles and Kyriakos C. Neanidisy, "Colonialism, Elite Formation and Corruption." SIRE Discussion Papers, Scottish Institute for Research in Economics (SIRE) 51 (2010); See also: Daron Acemoglu, S. Johnson and James A. Robinson, "The Colonial Origins of Comparative Development: An Empirical Investigation,” American Economic Review 91 no. 5 (2001): 1369-1401.

105. Susan Legêne, "The European Character of the Intellectual History of Dutch Empire." BMGN/ Low Countries Historical Review 132, no. 2 (2017): 110-120; Susan Legêne, Bambang Purwanto and Henk G.C. Schulte Nordholt, eds., Sites, Bodies and Stories. Imagining Indonesian History (Singapore: NUS Press, 2015). 


\section{REFERENCES}

Acemoglu, Daron, Johnson, S. and, James Robinson. "The Colonial Origins of Comparative Development: An Empirical Investigation." American Economic Review 91, no. 5 (2001): 1369-1401.

Allen, Amy. The End of Progress. Decolonizing the Normative Foundations of Critical Theory. New York: Columbia University Press, 2016.

Andersson, Staffan and Paul Heywood. "The Politics of Perception: Use and Abuse of Transparency International's Approach to Measuring Corruption." Political Studies 57, no. 4, (2009): 746-767.

Angeles, Luis and Kyriakos C. Neanidisy, "Colonialism, Elite Formation and Corruption", SIRE Discussion Papers, Scottish Institute for Research in Economics (SIRE), 2010.

Bloembergen, Marieke. De geschiedenis van de politie in Nederlands-Indië: uit zorg en angst. Amsterdam: Boom; Leiden: KITLV Uitgeverij, 2009.

Bloembergen, Marieke and Vincent Kuitenbrouwer. "A New Dutch Imperial History Connecting Dutch and Overseas Pasts." BMGN-Low Countries Historical Review (special issue) 128, no. 1 (2013): 1-5.

Boomgaard, Peter. "Human Capital, Slavery and Low Rates of Economic and Population Growth in Indonesia, 1600-1910." Slavery \& Abolition 24, no. 2 (2003): 83-96.

Bosma, Ulbe. "The Discourse on Free Labor and the Forced Cultivation System: The Contradictory Consequences of the Abolition of the Slave Trade in Colonial Java, 1811-1870." In Humanitarian Intervention and Changing Labor Relations: The Long-Term Consequences of the Abolition of the Slave Trade, edited by Marcel van der Linden. Leiden: Brill, 2011.

Bosma, Ulbe. The Sugar Plantation in India and Indonesia: Industrial Production, 1770-2010. Cambridge: Cambridge University Press, 2013.

Breman, Jan. Koelies, planters en koloniale politiek. Het arbeidsregime op de grootlandbouwondernemingen aan Sumatra's oostkust in het begin van de twintigste eeuw Dordrecht: Foris, 1987.

Breman, Jan. "Het beest aan banden? De koloniale geest aan het begin van de twintigste eeuw." Bijdragen tot de Taal-, Land-en Volkenkunde 144, no. 1 (1988): 19-43.

Briët, Kees. Het proces van Rijck van Prehn en Johannes Wilhelmus Winter. Een bijzondere zaak voor het Hooggerechtshof van Nederlands-Indië in 1820. Hilversum: Verloren, 2012.

Burbank, Jane and Frederick Cooper. Empires in World History: Power and the Politics of Difference. Princeton, NJ: Princeton University Press, 2010.

Burton, Antoinette M.. "Introduction: The Unfinished Business of Colonial Modernities." In Gender, Sexuality, and Colonial Modernities, edited by Antoinette M. Burton, 1-16. London: Routledge, 1999.

Carey, Peter. "Revolutionary Europe and the Destruction of Java's Old Order, 1909-1830." In The Age of Revolutions in Global Context, c. 1760-1840, 
edited by David Armitage and Sanjay Subrahmanyam, 167-188. Basingstoke: Palgrave Macmillan, 2009.

Cooper, Frederick. Colonialism in Question. Theory, Knowledge, History. Berkeley and Los Angeles and London: University of California Press, 2005.

Chakrabarty, Dipesh. Provincializing Europe: Postcolonial Thought and Historical Difference. Princeton: Princeton University Press, 2000.

Dick, Howard W. and Vincent J.H. Houben. The Emergence of a National Economy. An Economic History of Indonesia, 1800-2000. Honolulu: University of Hawai'i Press, 2002.

Dijkstra, J.F.. De corruptie in de Nederlandsch-Indische ambtenaarswereld, of: Mr. Rhemrev als regeeringscommissaris door J.F. Dijkstra, Planter. Rotterdam: Masereeuw \& Bouten, 1906.

Dirks, Nicolas B. The Scandal of Empire: India and the Creation of Imperial Britain. Cambridge MA: Harvard University Press, 2006.

Doel, Wim van den. Het Rijk van Insulinde: opkomst en ondergang van een Nederlandse kolonie. Amsterdam: Prometheus, 1996.

Egbedi, Hadassah. “By Ignoring Corruption's Colonial Roots, Cameron's Summit Was Destined to Fail", The Guardian, 13 May 2016. https:// www.theguardian.com/world/2016/may/13/ignoring-corruptions-colonialroots-camerons-summit-was-destined-to-fail.

Emmer, Piet and Jos Gommans. Rijk aan de Rand van de Wereld: de geschiedenis van Nederland overzee 1600-1800. Amsterdam: Bert Bakker, 2012.

Engels, Jens Ivo. Die Geschichte der Korruption.Von der Früben Neuzeit bis 20. Jahrbundert. Frankfurt: Fischer Verlag, 2014.

Engels, Jens Ivo. "Corruption and Anticorruption in the Era of Modernity and Beyond." In Anticorruption in History. From Antiquity to the Modern Era, edited by Ronald Kroeze, André Vitoria and Guy Geltner, 167-180. Oxford: Oxford University Press, 2018.

Fakih, Farabi. The Rise of the Managerial State in Indonesia. Institutional Transition During the Early Independence Period. PhD diss., Universiteit Leiden, 2014.

Fasseur, Cees. "Nederland en het Indonesische nationalisme. De balans nog eens opgemaakt." BMGN-Low Countries Historical Review 99, no. 1 (1984): $21-45$.

Fasseur, Cees. De Indologen. Ambtenaren voor de Oost 1825-1950. Amsterdam: Aula, 2003, 3rd edition.

Frankema, Ewout and Frans Buelens, Colonial Exploitation and Economic Development. The Belgian Congo and the Netherlands Indies Compared. London: Routledge, 2013.

Guignard, Didier. L'Abus de pouvoir dans l'Algérie coloniale (1880-1914). Visibilité et singularité. Nanterre: Presses universitaires de Paris Ouest, 2010.

Graaf, Beatrice de. Tegen de terreur. Hoe Europa veilig werd na Napoleon. Amsterdam: Prometheus, 2018.

Hartley, L. P. The Go Between. London: Hamish Hamilton, 1953. 
Henley, David. "Credit and Debt in Indonesian History: An Introduction." In Credit \& Debt in Indonesia, 860-1930: From Peonage to Pawnshop, from Kongsi to Cooperative, edited by David Henley and Peter Boomgaard, 1-40. Singapore: Institute of Southeast Asian Studies; Leiden, Netherlands: KITLV Press, 2009.

Kennedy, James and Ronald Kroeze. "The Paradox of "A High Standard of Public Honesty": A Long-Term Perspective on Dutch History." In Anticorruption in History. From Antuiqity to the Modern Era, edited by Ronald Kroeze, André Vitória and Guy Geltner, 211-224. Oxford: Oxford University Press, 2018.

Kerkhoff, Toon. Hidden Morals. Explicit Scandals. PhD diss., Universiteit Leiden, 2012.

Kerkhoff, Toon, Ronald Kroeze, Pieter Wagenaar and Michel Hoenderboom, A History of Dutch Corruption and Public Morality (1648-1940). Newcastle upon Tyne: Cambridge Scholars Publishers, 2020.

Kerkhoff, Toon, Ronald Kroeze and Pieter Wagenaar, "Corruption and the Rise of Modern Politics in Europe in the Eighteenth and Nineteenth Centuries. A Comparison Between France, the Netherlands, Germany and EnglandIntroduction." Journal for Modern European History 11, no. 1 (2013): 1930 .

Koh, Keng We, "Review-article: Re-thinking the Colonial Transition: The Case of Java's Northeast Coast 1740-1850." Journal of Southeast Asian Studies 38, no. 2 (June 2007): 385-393.

Koekkoek, René. "Envisioning the Dutch Imperial Nation-State in the Age of Revolutions." In The Dutch Empire Between Ideas and Practice, 1600-2000, edited by René Koekkoek, Anne-Isabelle Richard and Arthur Weststeijn, 135157. Cambridge: Cambridge University Press, 2019.

Kwee, Hui Kian. "Chinese Economic Dominance in Southeast Asia: A Longue Duree Perspective." Society and History 55, no. 1 (January 2013): 5-34.

Kwee, Hui Kian. The Political Economy of Java's Northeast Coast. c. 1740-1800: Elite Synergy. Leiden: Brill, 2006.

Kroeze, Ronald. "Dutch Political Modernization and the Billiton Case (18821892). The Usefulness of a Neoclassical Contextual Approach to Corruption." In Integration, Legitimation, Koruption. Politische Patronage in Früher Neuzeit und Moderne, edited by Ronald G. Asch, Birgit Emich, and Jens Ivo Engels, 285-307. Frankfurt and New York: Peter Lang, 2011.

Kroeze, Ronald. "The Rediscovery of Corruption in Western Democracies." In Corruption and Governmental Legitimacy: A Twenty-First Century Perspective, edited by Jonathan Mendilow and Ilan Peleg, 21-40. Lanham: Rowman and Littlefield Publishers, 2016.

Kroeze, Ronald, Andre Vitória and Guy Geltner, eds., Anticorruption in History: From Antiquity to the Modern Era. Oxford: Oxford University Press, 2019. 
Legêne, Susan. "The European Character of the Intellectual History of Dutch Empire." BMGN-Low Countries Historical Review 132, no. 2 (2017): 110120.

Legêne, Susan, Bambang Purwanto and Henk Schulte Nordholt, eds.,. Sites, Bodies and Stories. Imagining Indonesian History. Singapore: NUS Press, 2015.

Legêne, Susan. De bagage van Blomboff en Van Breugel: Japan, Java, Tripoli en Suriname in de negentiende-eeuwse Nederlandse cultuur van het imperialisme. Amsterdam: Koninklijk Instituut voor de Tropen, 1998.

Lindblad, Thomas. Foreign Investment in South East Asia. London: Palgrave, 1998.

Lindeman, Mary. "Dirty Politics or "Harmonie"? Defining Corruption in Early Modern Amsterdam and Hamburg." Journal of Social History 45, no. 3 (2012): 582-604.

Lintum, C. te. Een eeuw van vooruitgang, 1813-1913. Zutphen: Thieme, 1913.

Locher Scholten, Elsbeth. Sumatran Sultanate and Colonial State: Jambi and the Rise of Dutch Imperialism, 1830-1907. Studies on Southeast Asia. Ithaca: Cornell University, 2004.

Mattina, Cesare, Frédéric Monier, Olivier Dard and Jens Ivo Engels, eds. Dénoncer la corruption: Chevaliers blancs, pamphlétaires et promoteurs de la transparence à l'époque contemporaine. Paris: Demopolis, 2018.

Monier, Frédéric, Oliver Dard and Andreas Fahrmeir, eds. Scandales et corruption à l'époque contemporaine. Paris: Armand Colin, 2014.

Multatuli [Eduard Douwes Dekker], Max Havelaar. Of de Koffiveilingen van de Nederlandse Handelmaatschappy. Amsterdam: Antheneum-Polak \& Van Gennep, 2011 [1860].

Niertrasz, Chris. In the Shadow of the Company: The Dutch East India Company and Its' Servants in the Period of Its' Decline 1740-1796. Leiden: Brill, 2012.

Paul, A.T.. "Korruption als Europaische Erbe?" In Geld-Geschenke-Politik: Korruption Im Neuzeitlichen Europa. Historisch Zeitschrift, edited by Jens Ivo Engels, Andreas Fahrmeir and Alexander Nützenadel, 275-306. Munchen: Oldenbourg, 2009.

Pierce, Steven. "Looking Like a State: Colonialism and the Discourse of Corruption in Northern Nigeria." Comparative Studies in Society and History 48, no. 4 (2006): 887-914.

Phijffer, Tom. Het gelijk van Multatuli het handelen van Eduard Douwes Dekker in rechtshistorisch perspectief. Amsterdam: Uitgeverij Bas Lubberhuizen, 2000.

Poortinga, Eelkje. De scheiding tussen publiek-en privaatrecht bij Johan Rudolph Thorbecke (1798-1872). Nijmegen: Ars Aequi Libri, 1987.

Purwanto, Bambang. "Entertain People, Accumulate Capital: Indonesian Military Entrepeneurship in the 1950s and 1960s." In Promises and Predicaments: Trade and Entrepreneurship in Colonial and Independent Indonesia in the 19th and 20th Centuries, edited by Alicia Schrikker and Jeroen Touwen, 151-162. Singapore: NUS Press, 2015. 
Purwanto, Bambang. "Economic Decolonization and the Rise of Indonesian Military Business." In Indonesian Economic Decolonization in Regional Perspective, edited by Thomas Lindblad and Peter Post, 39-58. Leiden: KITLV Press, 2009.

Raben, Remco. "A New Dutch Imperial History? Perambulations in a Prospective Field." BMGN-Low Countries Historical Review 128, no. I (2013): $5-30$.

Ravensbergen, Sanne. "Rule of Lawyers: Liberalism and Colonial Judges in Nineteenth-Century Java." In The Dutch Empire Between Ideas and Practice, 1600-2000, edited by René Koekkoek, Anne-Isabelle Richard and Arthur Weststeijn, 159-182. Cambridge: Cambridge University Press, 2019.

Ravesteijn, W. van. Het Djambi-schandaal. Amsterdam: Brochurehandel der Communistische Partij in Nederland, 1921.

Rubinstein, William. D. "The End of "Old Corruption" in Britain 1780-1860." Past and Present 101, no. 1 (1983): 55-86.

Saha, Jonathan. Law, Disorder and the Colonial State. Corruption in Burma ca. 1900. Basingstoke: Palgrave Macmillan, 2013.

Said, Edward. Orientalism. London: Routledge and Kegan Paul, 1978.

Schrikker, Alicia. "Restoration in Java 1815-1830: A Review." BMGN-Low Countries Historical Review 130, no. 4 (2015): 132-144.

Sens, Angelie. De kolonieman: Johannes van den Bosch (1780-1844), volksverheffer in naam van de koning. Amsterdam: Uitgeverij Balans, 2019.

Steiner, André. "Corruption in an Anticorruption State? East Germany under Communist Rule." In Anticorruption in History. From Antuiqity to the Modern Era, edited by Ronald Kroeze, André Vitória and Guy Geltner, 293-304. Oxford: Oxford University Press 2018.

Sutherland, Heather. The Making of a Bureaucratic Elite: The Colonial Transformation of the Javanese Priyayi. Singapore: Heinemann, 1979.

Tänzler, Dirk, K. Maras and A. Giannakopoulos. "The German Myth of a Corruption-Free Modern Country." In The Social Construction of Corruption in Europe, edited by Dirk Tänzler, K. Maras and A. Giannakopoulos, 87-105. Surrey: Ashgate, 2012.

Taselaar, Arjan. De Nederlandse koloniale lobby: ondernemers en de Indische politiek, 1914-1940. Leiden: Research School CNWS, School of Asian, African, and Amerindian Studies 1998.

Thiessen, Hillard von. "Korrupte Gesandte? Konkurrierende Normen in Der Diplomatie Der Frühen Neuzeit." In Korruption. Historische Annäherungen an Eine Grundfigur Politischer Kommunikation, edited by Niels Grüne and Simona Slanička, 205-220. Göttingen: Vandenhoeck \& Ruprecht, 2010.

Thiessen, Hillard von. "Korruption Und Normenkonkurrenz. Zur Funktion Und Wirkung Von Korruptionsvorwürfen Gegen Die Günstling-Minister Lerma Und Buckingham in Spanien Und England Im Frühen 17. Jahrhundert." In Geld-Geschenke-Politik: Korruption Im Neuzeitlichen Europa, edited by Jens Ivo Engels, Andreas Fahrmeir, and Alexander Nützenadel, 91-120. Munchen: Oldenbourg, 2009. 
Termorshuizen, G.. "Busken Huet en "het geval Hasselman” na honderd jaar.” De Gids 132, (1969): 139-149.

Vickers, Adrian. A History of Modern Indonesia. Cambridge: Cambridge University Press, 2005.

Waaldijk, Berteke and Susan Legêne. "Ethische politiek in Nederland. Cultureel burgerschap tussen overheersing, opvoeding en afscheid." In Het koloniale beschavingsoffensief. Wegen naar het nieuwe Indië 1890-1950, edited by Marieke Bloembergen and Remco Raben, 187-216. Leiden: KITLV Uitgeverij, 2009.

Wahid, Abdul. "In the shadow of opium. Tax farming and the political economy of colonial extraction in Java, 1807-1911." In Colonial Exploitation and Economic Development. The Belgian Congo and the Netherlands Indies compared, edited by Ewout Frankema and Frans Buelens, 109-129. London and New York: Routledge, 2013.

Walzer, Michael. "Liberalism and the Art of Separation." Political Theory 12, no. 3 (August 1984): 315-330.

Wertheim, Willem F. "Corruptie." In Geld en geweten. Een bundel opstellen over anderehalve eeuw Nederlands bestuur in de Indonesische archipel, deel 2: het tijdvak tussen 1900-1942, edited by C. Fasseur, 213-221. Den Haag: Martinus Nijhof, 1980. Originally published as Willem F. Wertheim. "Corruptie als sociologisch studieobject." In Corruptie, edited by Willem F. Wertheim and H.J. Brasz, 21-30. Assen: Van Gorcum 1961.

Zanden, Jan Luiten van and Daan Marks. An Economic History of Indonesia 1800-2010. London: Routledge, 2012.

Open Access This chapter is licensed under the terms of the Creative Commons Attribution 4.0 International License (http://creativecommons.org/licenses/ by $/ 4.0 /)$, which permits use, sharing, adaptation, distribution and reproduction in any medium or format, as long as you give appropriate credit to the original author(s) and the source, provide a link to the Creative Commons licence and indicate if changes were made.

The images or other third party material in this chapter are included in the chapter's Creative Commons licence, unless indicated otherwise in a credit line to the material. If material is not included in the chapter's Creative Commons licence and your intended use is not permitted by statutory regulation or exceeds the permitted use, you will need to obtain permission directly from the copyright holder.

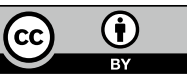

